\title{
Effects of nuclear respiratory factor-1 on apoptosis and mitochondrial dysfunction induced by cobalt chloride in $\mathrm{H} 9 \mathrm{C} 2$ cells
}

\author{
NAN NIU ${ }^{1 *}$, ZIHUA LI $^{2 *}$, MINGXING ZHU ${ }^{1}$, HONGLI SUN ${ }^{1}$, JIHUI YANG $^{1}$, \\ SHIMEI XU ${ }^{1}$, WEI ZHAO ${ }^{1}$ and RONG SONG ${ }^{3 *}$ \\ ${ }^{1}$ College of Basic Medicine, Ningxia Medical University, Yinchuan, Ningxia Hui Autonomous Region 750001; \\ ${ }^{2}$ School of Pharmacy, Tsinghua University, Beijing 100084; ${ }^{3}$ Department of Critical Care Medicine, \\ The Fifth Hospital of the Chinese People's Liberation Army, Yinchuan, Ningxia Hui Autonomous Region 750001, P.R. China
}

Received December 23, 2017; Accepted September 28, 2018

DOI: $10.3892 / \mathrm{mmr} .2019 .9839$

\begin{abstract}
Hypoxia-induced apoptosis occurs in various diseases. Cobalt chloride $\left(\mathrm{CoCl}_{2}\right)$ is a hypoxia mimic agent that is frequently used in studies investigating the mechanisms of hypoxia. Nuclear respiratory factor-1 (NRF-1) is a transcription factor with an important role in the expression of mitochondrial respiratory and mitochondria-associated genes. However, few studies have evaluated the effects of NRF-1 on apoptosis, particularly with regard to damage caused by $\mathrm{CoCl}_{2}$. In the present study, the role of NRF-1 in mediating $\mathrm{CoCl}_{2}$-induced apoptosis was investigated using cell viability analysis, flow cytometry, fluorescence imaging, western blotting analysis, energy metabolism analysis and reverse transcription-quantitative polymerase chain reaction. The present results revealed that the apoptosis caused by $\mathrm{CoCl}_{2}$ could be alleviated by NRF-1. Furthermore, overexpression of NRF-1 increased the expression of B-cell lymphoma-2, hypoxia inducible factor-1a and $N R F-2$. Also, cell damage induced by $\mathrm{CoCl}_{2}$ may be associated with depolarization of mitochondrial membrane potential, and NRF-1 suppressed this effect. Notably, the oxygen consumption rate $(\mathrm{OCR})$ was reduced in $\mathrm{CoCl}_{2}$-treated cells, whereas overexpression of NRF-1 enhanced the OCR,
\end{abstract}

Correspondence to: Professor Rong Song, Department of Critical Care Medicine, The Fifth Hospital of the Chinese People's Liberation Army, 893 Shengli South Street, Xingqing, Yinchuan, Ningxia Hui Autonomous Region 750001, P.R. China

E-mail: srlyk@163.com

Professor Wei Zhao, College of Basic Medicine, Ningxia Medical University, 1160 Shengli Street, Xingqing, Yinchuan, Ningxia Hui Autonomous Region 750001, P.R. China

E-mail: zw-6915@163.com

*Contributed equally

Key words: cobalt chloride, nuclear respiratory factor-1, hypoxia, mitochondrion, $\mathrm{H} 9 \mathrm{C} 2$ cells suggesting that NRF-1 had protective effects. In summary, the present study demonstrated that NRF-1 protected against $\mathrm{CoCl}_{2}$-induced apoptosis, potentially by strengthening mitochondrial function to resist $\mathrm{CoCl}_{2}$-induced damage to $\mathrm{H} 9 \mathrm{C} 2$ cells. The results of the present study provide a possible way for the investigation of myocardial diseases.

\section{Introduction}

Dysfunction caused by hypoxia is an important component of numerous diseases (1). Tissue hypoxia is induced by decreased blood flow, arterial blood oxygen partial pressure and interrupted blood flow (2). When oxygen supply is insufficient or the balance between $\mathrm{O}_{2}$ demand and supply is disrupted, distant organs can be damaged, and neuronal injury (2) or microcirculation disturbance in perfusion organs, such as the liver, kidneys and gastrointestinal tract (3), may occur. The heart is at the center of blood and oxygen supply to all organs. However, hypoxia is also a major contributor to cardiomyocyte pathophysiology, with a role in diseases including congenital heart disease, myocardial infarction (4-6) and ischemic heart disease $(7,8)$.

The metabolic center of oxygen consumption is the mitochondria, which can produce up to $90 \%$ of the adenosine triphosphate (ATP) required for cell function (9-12). Previous studies have demonstrated that the mitochondria act as a power source for the cell and as an effector of other critical events, including apoptosis and cell death $(13,14)$. Therefore, it is important to understand their function, particularly with regard to metabolism. In contrast to other subcellular structures that are regulated by karyogenes, mitochondria contain their own transcription system. Mitochondrial DNA (mtDNA) is a double-stranded circular DNA containing 37 genes and encoding 13 polypeptides that are involved in the synthesis of ATP $(15,16)$. Although $\sim 1,500$ proteins participate in the regulation of mitochondrial structure and function, because of the limited coding capacity of mtDNA, $<1 \%$ of these proteins are encoded by mitochondria, and the remaining proteins are encoded by nuclear genes (17-19). Therefore, the biological processes of mitochondria are regulated by both mitochondrial and nuclear genes. 
Nuclear respiratory factor-1 (NRF-1), which was initially discovered during the investigation of cytochrome $c$ transcriptional activation (20), is essential for early embryogenesis in mammals, and loss of NRF-1 results in a peri-implantation lethal phenotype. Furthermore, NRF-1 $1^{-/}$blastocysts exhibited decreased mtDNA amounts (21). NRF-1 also serves an important role in the integration of nuclear and mitochondrial interactions (20,22-24). For example, NRF-1 mediates the transcription of mtDNA by affecting the promoter region of mitochondrial transcription factor A (mtTFA; also termed Tfam) (25), thus altering mitochondrial biogenesis (26-28). Nuclear factor (NF) $-\mathrm{\kappa B}$ can regulate the NRF-1 gene directly via the lipopolysaccharide-receptor pathway, leading to increased mitochondrial mRNA transcription and enrichment of mtDNA copy number (29). Furthermore, in aerobic cardiac cells, NRF-1 is associated with the transcriptional control of complex II and prevention of pseudo-hypoxic gene expression (30).

Cobalt chloride $\left(\mathrm{CoCl}_{2}\right)$ is often used as a hypoxia mimic agent in vivo and in vitro $(31,32)$ and it have been demonstrated to activate hypoxia-associated signals, such as stabilizing hypoxia inducible factor- $1 \alpha$ (HIF-1 $\alpha)(33,34)$. HIF-1 $\alpha$ can be hydroxylated and then ubiquitinated for degradation by the proteasome in normoxic conditions (35-37); however, under hypoxic conditions or in the presence of low oxygen concentrations, the $\alpha$ subunit is not hydroxylated, allowing HIF- $1 \alpha$ to enter the nucleus inducing the transcription of certain hypoxia response elements (38-40).

Therefore, in the present study, it was aimed to further elucidate the role of NRF-1 in hypoxia. To this end, the effects of NRF-1 overexpression in H9C2 cardiomyoblasts on $\mathrm{CoCl}_{2}$-stimulated hypoxia were investigated.

\section{Materials and methods}

Materials. The lentiviral expression vector pLenti6.3NRF1-IRES2-EGFP and lentiviral packaging plasmids (pLP1, pLP2 and pLP/VSVG) were purchased from Invitrogen (Thermo Fisher Scientific, Inc., Waltham, MA, USA). H9C2 cells were purchased from cell bank of the Chinese Academy of Sciences (Shanghai, China). Plasmid extraction and purification kits purchased from Axygen (Corning Incorporated, Corning, NY, USA). TRIzol reagent, $0.25 \%$ Trypsin, Dulbecco's modified Eagle's medium (DMEM), fetal bovine serum (FBS) and 293T cells were purchased from Invitrogen (Thermo Fisher Scientific, Inc.). The Cell Counting Kit-8 (CCK-8) was purchased from TransGen Biotech (Beijing, China). Hoechst 33342 was purchased from Beyotime Institute of Technology (Haimen, China). TransScript Reverse Transcriptase and qPCR SuperMix were purchased from TransGen Biotech.

NRF-1 transfection. 293T packaging cells $\left(1 \times 10^{7}\right)$ were plated in $10-\mathrm{cm}$ plates before transfection. PLenti6.3-NRF1-IRES2-EGFP plasmids ( $3 \mu \mathrm{g}$ ) and $9 \mu \mathrm{g}$ packaging plasmids ( $3 \mu \mathrm{g}$ pLP1, $3 \mu \mathrm{g}$ pLP2 and $3 \mu \mathrm{g}$ pLP/VSVG) were co-transfected into the 293T cells using Lipofectamine ${ }^{\circledR}$ 2000 reagent (Invitrogen; Thermo Fisher Scientific, Inc.) and inoculated in a $10 \mathrm{~cm}$ culture dish before transfection. Virus-containing supernatant was isolated under 50,000 x g at $4{ }^{\circ} \mathrm{C}$ and collected after $2 \mathrm{~h}$. Virus was added to the H9C2 cells $\left(1 \times 10^{5} / \mathrm{ml}\right)$ in the presence of $8 \mu \mathrm{g} / \mathrm{ml}$ polybrene (Sigma-Aldrich; Merck KGaA, Darmstadt, Germany). Following transfection for $48 \mathrm{~h}$, the target cells were subjected to $1 \mu \mathrm{g} / \mathrm{ml}$ puromycin for selection. The transfected cells were designated as NRF1-transfected H9C2 (NRF1-H9C2) cells and empty virus-transfected as pLenti-H9C2 cells.

Cell culture and treatment. NRF1-H9C2 or pLenti-H9C2 cells $\left(5 \times 10^{6}\right)$ were cultured in $10-\mathrm{cm}$ culture plates in DMEM supplemented with 10\% FBS and $2 \mathrm{mM}$ glutamine and incubated in a humidified incubator with an atmosphere containing $5 \% \mathrm{CO}_{2}$ and $21 \% \mathrm{O}_{2}$ at $37^{\circ} \mathrm{C}$. Chemical hypoxia was induced by adding the hypoxia-mimetic agent $\mathrm{CoCl}_{2}$ (Sigma-Aldrich; Merck KGaA) at 200 or $400 \mu \mathrm{M}$, and cells were then incubated for 6 or $24 \mathrm{~h}(41,42)$.

Determination of cell viability. $5 \times 10^{4} \mathrm{NRF} 1-\mathrm{H} 9 \mathrm{C} 2$ and pLenti-H9C2 cells $\left(5 \times 10^{6}\right)$ were seeded in 96-well plates and treated with 200 or $400 \mu \mathrm{M} \mathrm{CoCl}_{2}$ for 6 or $24 \mathrm{~h}$. Subsequently, $10 \mu 1$ CCK-8 reagent was added to each well, and the plates were incubated at $37^{\circ} \mathrm{C}$ for $3 \mathrm{~h}$. Absorbance was measured at $450 \mathrm{~nm}$ using a microplate reader. The cell viability (\%) relative to the control was calculated as follows: Relative cell viability $(\%)=$ optical density $(\mathrm{OD})$ sample/OD control $\mathrm{x} 100$. Each group was analyzed using five wells, and the experiment was repeated at least three times.

Analysis of mitochondrial membrane potential (MMP). Cells $\left(5 \times 10^{5}\right)$ were seeded in 6 -well plates and the cells were stained with $2.5 \mathrm{nM}$ tetramethylrhodamine ethyl ester (Sigma-Aldrich; Merck $\mathrm{KGaA}$ ) for $30 \mathrm{~min}$ at $37^{\circ} \mathrm{C}(43)$, then washed twice with PBS and analyzed using an Accuri C6 flow cytometer (BD Biosciences, Franklin Lakes, NJ, USA) and BD Accuri C6 Software (version 1.0; BD Biosciences).

Analysis of apoptosis by Hoechst 33342 staining. Cells $\left(2 \times 10^{5}\right)$ were seeded in 24-well plates and propagated to $\sim 80 \%$ confluence, then washed with PBS twice, stained with Hoechst 33342 $(50 \mu \mathrm{g} / \mathrm{ml})$ at $37^{\circ} \mathrm{C}$, and incubated in the dark. After $20 \mathrm{~min}$, the nuclear morphology of the cells was observed to determine the occurrence of apoptosis using a fluorescence microscope.

Reverse transcription-quantitative polymerase chain reaction $(R T-q P C R)$ analysis. Total RNA was extracted using TRIzol reagent in accordance with the manufacturer's protocol. cDNA was synthesized from total RNA using Transcript Reverse Transcriptase (Transgene Biotech; the reaction system is presented as Table I) then incubated for $30 \mathrm{~min}$ at $42^{\circ} \mathrm{C}$ and heated at $85^{\circ} \mathrm{C}$ for $5 \mathrm{sec}$. Fluorescent qPCR was performed using Transcript Green Two-Step qRT-PCR Super Mix (Transgene Biotech). Specific primers were used to amplify $N R F-1, N R F-2, m t T F A, H I F-1 \alpha$, mitochondrial single stranded DNA binding protein $(m t S S B), \mathrm{Bcl}$-associated $\mathrm{X}$ protein (Bax), B-cell lymphoma-2 (Bcl-2), and $G A P D H$, as presented in Table II. All fluorescent qPCR assays were performed in duplicate $20-\mu 1$ reactions, and detection was carried out using a Light Cycler 2 real-time PCR machine (Bio-Rad Laboratories, Inc., Hercules, CA, USA). The thermocycling conditions were: $95^{\circ} \mathrm{C}$ for $2 \mathrm{~min}$ followed by 35 cycles of amplification 
Table I. cDNA reaction system.

\begin{tabular}{lc}
\hline Component & Volume \\
\hline Total RNA & $1 \mu \mathrm{l}(50 \mathrm{ng}-5 \mu \mathrm{g})$ \\
Oligo $(d T)$ Primer & $1 \mu \mathrm{l}$ \\
$10 \mathrm{mM}$ dNTPs & $1 \mu \mathrm{l}$ \\
$5 \times$ Buffer & $4 \mu \mathrm{l}$ \\
Ribonuclease Inhibitor & $0.5 \mu \mathrm{l}$ \\
TransScript $R T$ & $1 \mu \mathrm{l}$ \\
RNase-free Water & $11.5 \mu \mathrm{l}$ \\
Total volume & $20 \mu \mathrm{l}$ \\
\hline
\end{tabular}

$\left(95^{\circ} \mathrm{C}\right.$ for $15 \mathrm{sec}, 55^{\circ} \mathrm{C}$ for $30 \mathrm{sec}$ and $72^{\circ} \mathrm{C}$ for $\left.30 \mathrm{sec}\right)$. The data was quantified by $2^{-\Delta \Delta \mathrm{Cq}}$ method (44).

Western blotting. Cells were lysed using cell lysis buffer (Beyotime Institute of Biotechnology). Homogenate protein concentrations were measured using a bicinchoninic acid protein assay kit (Beyotime Institute of Biotechnology). Cell lysates $(50 \mu \mathrm{g})$ were separated by sodium dodecyl sulfate-polyacrylamide gel electrophoresis on $12 \%$ gels and transferred onto polyvinylidene difluoride membranes (EMD Millipore). The membranes were blocked with 5\% nonfat milk in PBS containing 0.1\% Tween-20 for $2 \mathrm{~h}$ at room temperature and then incubated overnight at $4^{\circ} \mathrm{C}$ with anti-NRF1 (1:1,000; ab175932), anti-Bax (1:1,000; ab32503), anti-Bcl-2 (1:500; ab59348), anti-poly(ADP-ribose) polymerase 1 (PARP; 1:500; ab32064) and anti- $\beta$-actin (1:2,000; ab49900); all from Abcam (Cambridge, UK)]. Subsequently, the membranes were incubated with horseradish peroxidase-linked secondary anti-rabbit (1:5,000; BA1054; Boster Biological Technology, Pleasanton, CA, USA) at room temperature for $2 \mathrm{~h}$. Antibody-bound protein was detected using a chemiluminescent detection kit (Super Signal West Dura; Thermo Fisher Scientific, Inc.), exposed to X-ray film, and densitometry was quantified by Image Lab version 5.1 (Bio-Rad Laboratories, Inc.).

Annexin V-allophycocyanin (APC)/7-aminoactinomycin D (7-AAD) staining. Cells were seeded in 24-well plates $\left(2 \times 10^{5}\right.$ per well) and cultured with medium containing $400 \mu \mathrm{M}$ $\mathrm{CoCl}_{2}$ for $6 \mathrm{~h}$. Apoptotic cells were measured by flow cytometry using Annexin V-APC and 7-AAD Apoptosis Detection reagent (BD Biosciences). Briefly, cell were digested, collected, washed and incubated at room temperature for $10 \mathrm{~min}$ with $1 \mathrm{X}$ binding buffer containing Annexin V-conjugated APC and 7-AAD. Annexin V-APC staining was used to detect exposure of phosphatidylserine. 7-AAD is able to penetrate the cells when cell apoptosis and cell death occurs. Annexin V-APC was used to detect early apoptotic cells, and Annexin V-APC and 7-AAD were used to detect necrotic cells or/and nonviable apoptotic cells. Cells were detected by BD Accuri C6 Flow Cytometer and analyzed by BD Accuri ${ }^{\mathrm{TM}}$ C6 Software version 1.0 (BD Biosciences).

Detection of energy metabolism. An XFe24 Analyzer (Seahorse Bioscience; Agilent Technologies, Inc., Santa
Table II. Primers used for reverse transcription-quantitative polymerase chain reaction.

\begin{tabular}{lll}
\hline Gene & Direction & \multicolumn{1}{c}{ Sequence (5'-3') } \\
\hline$N R F-1$ & Sense & CCACGTTGGATGAGTACACG \\
& Antisense & CTGAGCCTGGGTCATTTTGT \\
$N R F-2$ & Sense & CCGCTACACCGACTACGATT \\
& Antisense & ACCTTCATCACCAACCCAAG \\
$m t T F A$ & Sense & GCTTCCAGGAGGCTAAGGAT \\
& Antisense & CCCAATCCCAATGACAACTC \\
HIF-1 $\alpha$ & Sense & TGCTGATTTGTGAACCCATT \\
& Antisense & TCTGGCTCATAACCCATCAA \\
$m t S S B$ & Sense & AGCCAGCAGTTTGGTTCTTG \\
& Antisense & CCACTTTGCCTTCCACAAAT \\
Bax & Sense & TTGCTACAGGGTTTCATCCA \\
& Antisense & CTGAGACACTCGCTCAGCTT \\
Bcl-2 & Sense & GAGTACCTGAACCGGCATCT \\
& Antisense & GAAATCAAACAGAGGTCGCA \\
GAPDH & Sense & ACAGCAACAGGGTGGTGGAC \\
& Antisense & TTTGAGGGTGCAGCGAACTTT \\
\hline
\end{tabular}

NRF-1, nuclear respiratory factor 1 ; mtTFA, mitochondrial transcription factor; HIF-1 $\alpha$, hypoxia inducible factor- $1 \alpha$; mtSSB, mitochondrial single stranded DNA binding protein; Bax, Bcl-associated X protein; Bcl-2, B-cell lymphoma-2.

Clara, CA, USA) was used to detect cellular energy, and XF Cell Mito Stress Tests (Seahorse Bioscience; Agilent Technologies, Inc.) were used to detect oxygen consumption rate. Briefly, the day before the assay, $1 \times 10^{6}$ cells were seeded in Seahorse 24-well XF Cell Culture Microplates, and the cells were then allowed to grow overnight in a cell culture incubator containing $5 \% \mathrm{CO}_{2}$ and $95 \%$ air at $37^{\circ} \mathrm{C}$. The cells were then treated with $400 \mu \mathrm{M} \mathrm{CoCl}_{2}$ at $37^{\circ} \mathrm{C}$ for 6 h. Additionally, a Hydrate Sensor Cartridge was placed in a non- $\mathrm{CO}_{2}$ incubator $\left(37^{\circ} \mathrm{C}\right)$ overnight. The day of the assay, cells were washed with XF Glycolysis Stress Test Assay Medium, stock compounds [1 $\mu \mathrm{M}$ oligomycin, $2 \mu \mathrm{M}$ carbonyl cyanide p-trifluoromethoxyphenylhydrazone (FCCP) and $0.5 \mu \mathrm{M}$ rotenone/antimycin $\mathrm{A}]$ were added, and the cartridge ports were loaded. Following setting up the program on an XF Controller, the plate was placed in the instrument for testing. OCR was measured for about $3 \mathrm{~min}$ to detect basic OCR. Following baseline measurements, OCR was detected after injection of oligomycin, then FCCP was injected and the maximal OCR was measured. Non-mitochondrial oxygen consumption level was detected after the injection of rotenone/antimycin A.

Statistical analysis. Data were expressed as the mean \pm standard error. Statistical significance was assessed by two-tailed Student's t-tests or one-way analysis of variance with post hoc comparisons using the Student-Newman-Keuls test with GraphPad Prism 5.0 (GraphPad Software, Inc., La Jolla, CA, USA). $\mathrm{P}<0.05$ was considered to indicate a statistically significant difference. 
A

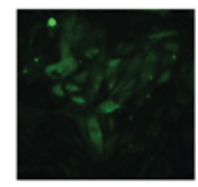

pLenti-H9C2

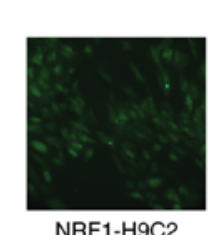

NRF1-H9C2
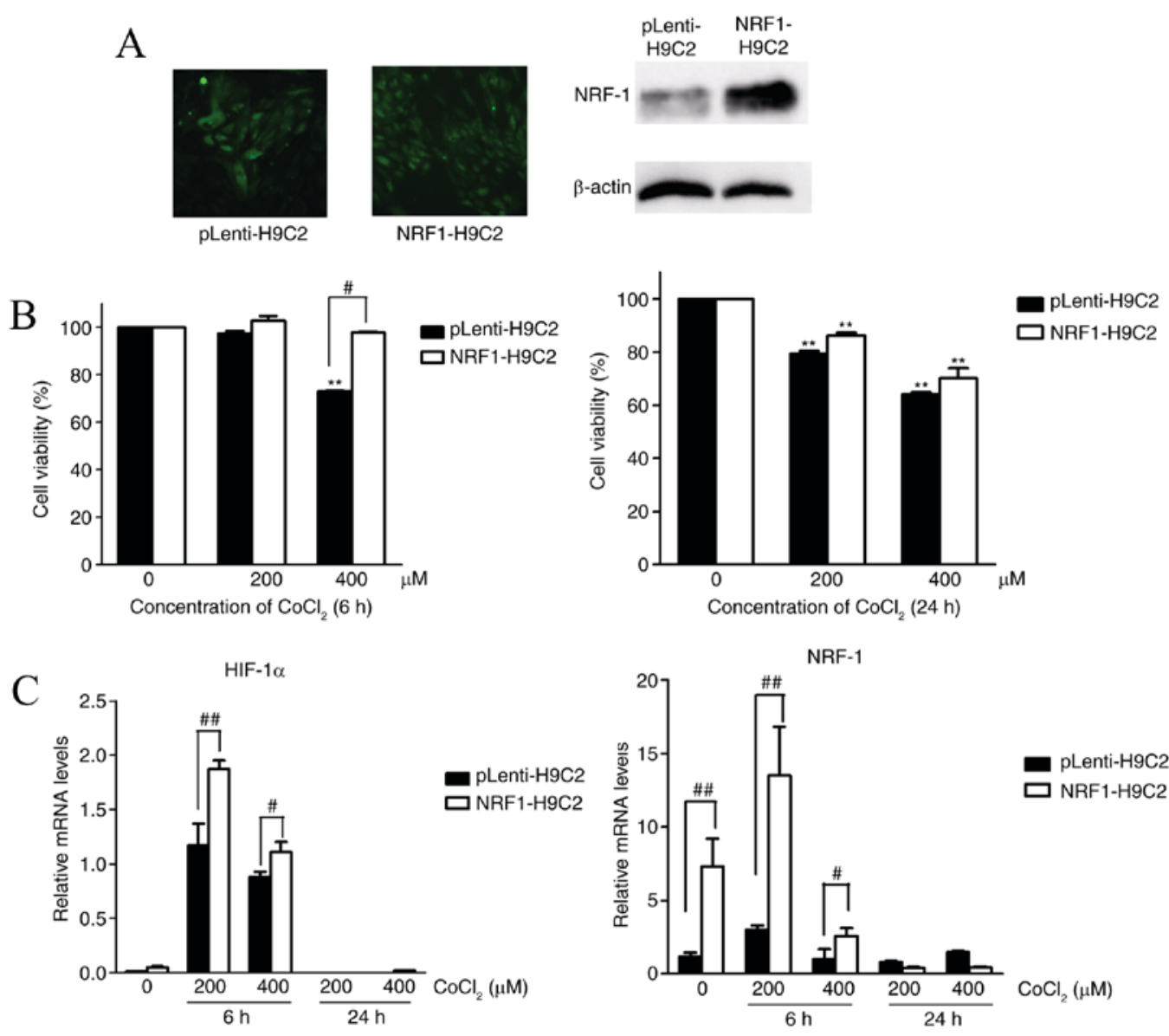

NRF-2

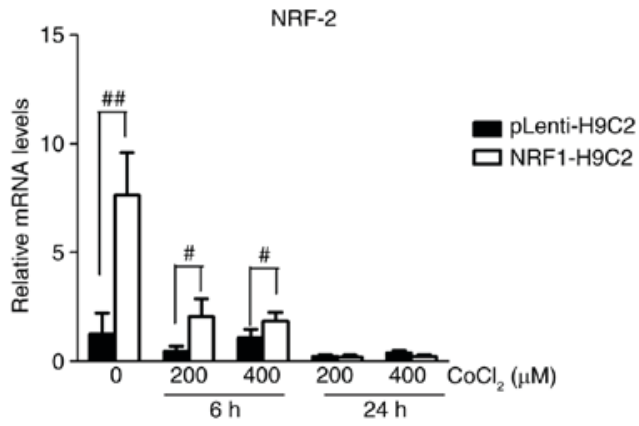

Figure 1. Effects of NRF-1 on the viability and mRNA expression levels of $H I F-1 \alpha, N R F-1$ and $N R F-2$ of $\mathrm{H} 9 \mathrm{C} 2$ cells. CoCl ${ }_{2}$-treated $\mathrm{H} 9 \mathrm{C} 2$ cells were cultured in DMEM plus $10 \%$ FBS containing 200 or $400 \mu \mathrm{M} \mathrm{CoCl}_{2}$ for 6 or $24 \mathrm{~h}$. (A) GFP expression in lentiviral vector-transfected H9C 2 cells, as observed by fluorescence microscopy (left); western blot analysis of NRF-1 expression levels in pLenti-H9C2 and NRF1-H9C2 cells (right). (B) CCK-8 assays were used to detect cell viability following treatment of pLenti-H9C2 and NRF1-H9C2 cells with 200 or $400 \mu \mathrm{M} \mathrm{CoCl}_{2}$ for 6 or 24 h. (C) Reverse transcription-quantitative polymerase chain reaction was used to analyze $H I F-1 \alpha, N R F-1$ and NRF-2 mRNA expression levels in pLenti-H9C2 and NRF1-H9C2 cells. ${ }^{* *} \mathrm{P}<0.01$ vs. the $0 \mu \mathrm{M} \mathrm{CoCl}_{2}$ group; ${ }^{\#} \mathrm{P}<0.05,{ }^{\# \#} \mathrm{P}<0.01$ vs. pLenti-H9C2 cells. $\mathrm{CoCl}_{2}$, cobalt chloride; HIF, hypoxia inducible factor; NRF, nuclear respiratory factor.

\section{Results}

Overexpression of NRF-1 alleviates the $\mathrm{CoCl}_{2}$-induced decrease in cell viability. To elucidate the role of NRF-1 in hypoxia caused by $\mathrm{CoCl}_{2}$ in $\mathrm{H} 9 \mathrm{C} 2$ cells, $\mathrm{H} 9 \mathrm{C} 2$ cells were transfected with NRF-1 overexpression lentiviral recombinant vector (NRF1-H9C2) or empty viral vector (pLenti-H9C2). Western blotting revealed that NRF-1 was upregulated in NRF1-H9C2 cells (Fig. 1A).

Subsequently, NRF1-H9C2 and pLenti-H9C2 cells were treated with 200 or $400 \mu \mathrm{M} \mathrm{CoCl}_{2}$ for 6 or $24 \mathrm{~h}$, and CCK- 8 assays were used to detect cell viability. The results demonstrated that the $\mathrm{CoCl}_{2}$-treated cells for $24 \mathrm{~h}$ had lower survival ability than the untreated cells (Fig. 1B). NRF1-H9C2 cells treated with $400 \mu \mathrm{M} \mathrm{CoCl}_{2}$ for $6 \mathrm{~h}$ demonstrated higher cell viability than pLenti-H9C2 cells. However, after 24 h treatment, there was no significant difference between NRF1-H9C2 and pLenti-H9C2 cells. RT-qPCR was performed to detect the mRNA expression of NRF-1,NRF-2 and HIF-1 $\alpha$. As described above, $\mathrm{CoCl}_{2}$ can stabilize HIF-1 $\alpha$ (33,34). Furthermore, the data demonstrated that HIF-1 $\alpha$ was expressed at low levels in both groups under normal conditions, whereas treatment with 200 or $400 \mu \mathrm{M} \mathrm{CoCl}_{2}$ for $6 \mathrm{~h}$ caused HIF-1 $\alpha$ mRNA levels to increase significantly in NRF1-H9C2 and pLenti-H9C2 cells, suggesting a response to hypoxia. However, it was also identified that the levels of HIF-1 $\alpha$ mRNA in NRF1-H9C2 cells 
were higher compared with pLenti-H9C2 cells. One possible reason may be that $\mathrm{NRF}-1$ possesses a direct regulation on $H I F-1 a$, but NRF-1 had almost no elevation effect on HIF-1a in non- $\mathrm{CoCl}_{2}$ treated cells, so another possible mechanism for the increased levels of HIF-la in the experiments was that it was affected by some genes that were activated or inactivated by $\mathrm{CoCl}_{2}$, and those genes were also influenced by NRF-1. $\mathrm{CoCl}_{2}$ can simulate hypoxia, which can also regulate the levels of HIF-1a. Theoretically, the levels of HIF-1a could be enhanced by $\mathrm{CoCl}_{2}$ in the experiments of the present study, but it is puzzling that $400 \mu \mathrm{m} \mathrm{CoCl}{ }_{2}$ could not promote the levels of $H I F-l a$ as did $200 \mu \mathrm{m} \mathrm{CoCl}_{2}$, and that NRF-1 also dropped to a low levels in $400 \mu \mathrm{m} \mathrm{CoCl}{ }_{2}$-treated cells. Thus, the increase of $\mathrm{HIF}$ - $\mathrm{la}$ levels caused by $\mathrm{CoCl}_{2}$ existed in certain conditions: A certain concentration of $\mathrm{CoCl}_{2}(200 \mu \mathrm{m})$ could cause stress effect of H9C2 cells in a short time $(6 \mathrm{~h})$, but when $\mathrm{CoCl}_{2}$ exceeded a certain level (400 $\mu \mathrm{m}$ for $6 \mathrm{~h}, 200 / 400 \mu \mathrm{m}$ for $24 \mathrm{~h}$ ), it would cause downstream effects on some genes like $N R F-1$ and HIF-1a. Therefore NRF-1 and HIF-la may have a special regulatory role in the presence of $\mathrm{CoCl}_{2}$; something which requires further study.

Overexpression of NRF-1 can reduce apoptosis trigged by $\mathrm{CoCl}_{2}$. The decrease in $\mathrm{H} 9 \mathrm{C} 2$ cell viability induced by $\mathrm{CoCl}_{2}$ may be due to apoptosis. Therefore, the nuclear morphology of $\mathrm{CoCl}_{2}$-treated cells using Hoechst 33342 staining was first examined. As shown in Fig. 2A, round and weakly stained cells were observed prior to treatment. However, $\mathrm{CoCl}_{2}$-treated cells demonstrated clear pyknosis and strong blue staining. The number of apoptotic nuclei was significantly lower in NRF1-H9C2 cells compared with that in pLenti-H9C2 cells.

Subsequently, flow cytometry was performed to analyze apoptosis in NRF1-H9C2 and pLenti-H9C2 cells. The results demonstrated that the apoptosis rates of both types of $\mathrm{CoCl}_{2}$-treated cells were significantly increased, although NRF1-H9C2 cells exhibited a relatively low rate of apoptosis (Fig. 2B). The expression of the Bcl-2 and Bax were also detected (Fig. 2C and D). Notably, in NRF1-H9C2 cells, the expression of the $\mathrm{Bcl}-2$, which encodes an anti-apoptotic molecule, maintained a higher level compared with that in pLenti-H9C2 cells. The expression of Bax, which encodes a pro-apoptotic molecule, was increased in $\mathrm{CoCl}_{2}$-treated cells; however, there were no obvious differences between NRF1-H9C2 and pLenti-H9C2 cells, which might indicate that NRF-1 has no inhibitory effect on Bax. The levels of PARP, which is the cleavage substrate of caspase, were higher in $\mathrm{CoCl}_{2}$-treared pLenti-H9C2 cells compared with that in NRF1-H9C2 cells. Based on these findings, the decrease in H9C2 cell viability may be partially due to the induction of apoptosis by $\mathrm{CoCl}_{2}$, and the presence of NRF-1 may have an inhibitory effect on apoptosis.

Effects of NRF-1 on MMP in CoCl $\mathrm{Cl}_{2}$-treated H9C2 cells. Multiple studies have demonstrated that MMP is an important index of apoptosis (45-48), MMP plays an important role in mitochondrial function and decline of MMP caused by stress can lead to mitochondrial dysfunction. In Fig. 3A, the red curve represented the untreated cells and the blue curve represented the $\mathrm{CoCl}_{2}$-treated cells, which suggested the reduction of
MMP level. In normal conditions, MMP in both groups maintained in high levels. However, changes in MMP level in both groups were observed following treatment with $400 \mu \mathrm{M} \mathrm{CoCl}_{2}$ for $6 \mathrm{~h}$, which exhibited the decline of MMP level, revealing the damaging effects of $\mathrm{CoCl}_{2}$ on mitochondrial function. The results of the present study also demonstrated that MMP levels in pLenti-H9C2 cells was lower compared with NRF1-H9C2 cells. A previous study identified that apoptosis was accompanied by the decline of MMP (45), data from the present study demonstrated that the overexpression of NRF-1 could alleviate the decrease of MMP, suggesting a protective effect of NRF-1 on mitochondria. In addition, $m t T F A$ and $m t S S B$ mRNA levels were significantly altered following treatment with $\mathrm{CoCl}_{2}$, with the mRNA levels remaining higher in NRF1-H9C2 cells than in pLenti-H9C2 cells. These data indicated that overexpression of NRF-1 could alleviate the decrease in MMP, potentially by affecting the expression levels of mitochondria-associated genes, such as $m t T F A$ and $m t S S B$ (Fig. 3B).

Overexpression of NRF-1 increases the oxygen consumption in $\mathrm{CoCl}_{2}$-treated $\mathrm{H} 9 \mathrm{C} 2$ cells. OCRs were used as an index of mitochondrial respiratory capacity $(49,50)$. Under normal conditions, OCRs were similar in NRF1-H9C2 and pLenti-H9C2 cells, suggesting that there were no differences in mitochondrial respiratory capacity between the two groups (Fig. 4A and B) under normal conditions. Following treatment of cells with $400 \mu \mathrm{M} \mathrm{CoCl}_{2}$ for $6 \mathrm{~h}$, the basic and maximum OCRs were decreased in both NRF1-H9C2 and pLenti-H9C2 cells, although the OCR in NRF1-H9C2 cells was relatively higher than that in pLenti-H9c2 cells. The above results indicated that NRF-1 may enhance the mitochondrial respiratory capacity to resist $\mathrm{CoCl}_{2}$-dependent impairment in $\mathrm{H} 9 \mathrm{C} 2$ cells.

\section{Discussion}

Hypoxia is a common cause of pathological damage to organs, including the heart, where brief and rapid hypoxia can cause irreversible damage. The heart is a unique organ that pumps blood into various tissues, and compared with other parts of the body, hypoxia in the heart results in serious consequences $(7,8)$. Cardiomyocytes are the structural and functional units of the heart $(51,52)$. Because adult cardiomyocytes lose their ability to proliferate (52-54), H9C2 cells, a proliferating cardiomyocyte cell line, has often used to observe the effect of hypoxia on cardiomyocytes. Many types of hypoxia can be attributed to the loss of oxygen caused by inadequate tissue perfusion or a drop in systemic oxygen partial pressure in the arterial blood (55). As described above, $\mathrm{CoCl}_{2}$ is a well-known hypoxia-mimetic chemical reagent that is widely used in many hypoxia studies (56-59). In the present study, H9C2 cardiomyocytes were exposed to two different concentrations of $\mathrm{CoCl}_{2}$, which resulted in a decrease in cell viability consistent with a previous study in which $\mathrm{CoCl}_{2}$ was reported to behave as a cytotoxic agent $(60,61)$. The present data also demonstrated the protective effects of NRF-1 on $\mathrm{CoCl}_{2}$-treated $\mathrm{H} 9 \mathrm{C} 2$ cells, an effect that had not been previously reported. Although multiple studies have reported that NRF-1 has protective effects on cells under stress conditions (62-64), these findings led us to explore the role of NRF-1, and particularly the protective mechanisms of NRF-1 in $\mathrm{CoCl}_{2}$-treated cells. 
A

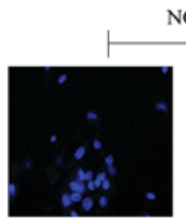

pLenti-H9C2
NC

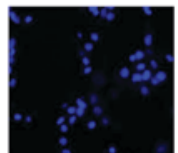

NRF1-H9C2

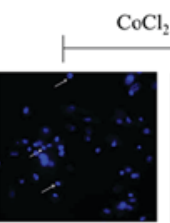

pLenti-H9C2

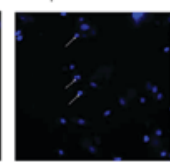

NRF1-H9C2

B
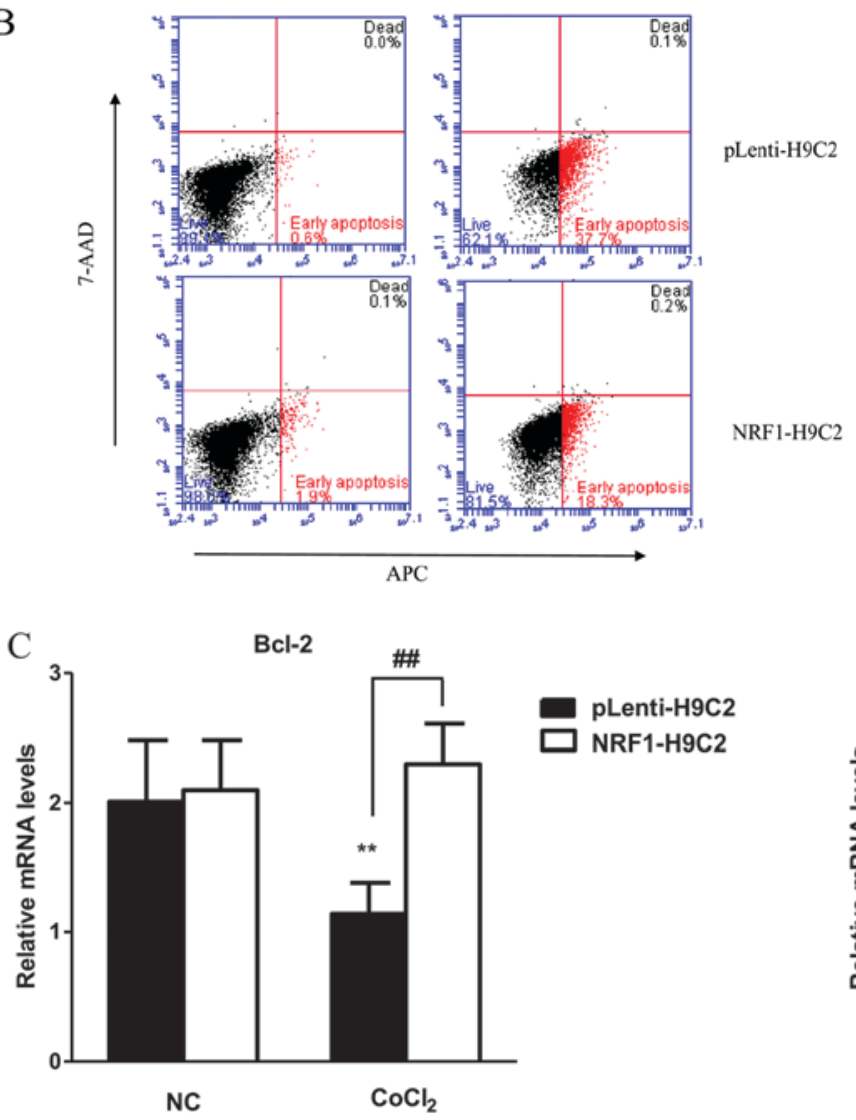

D

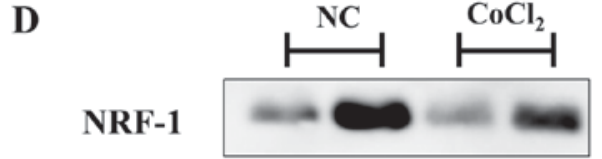

$\beta$-actin
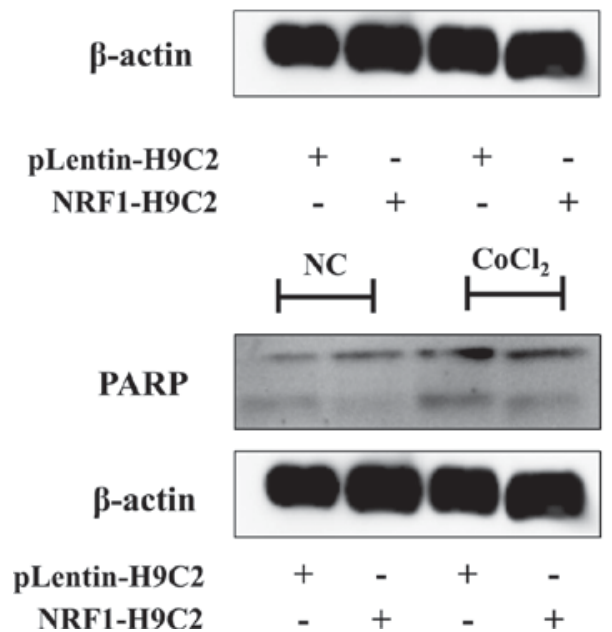
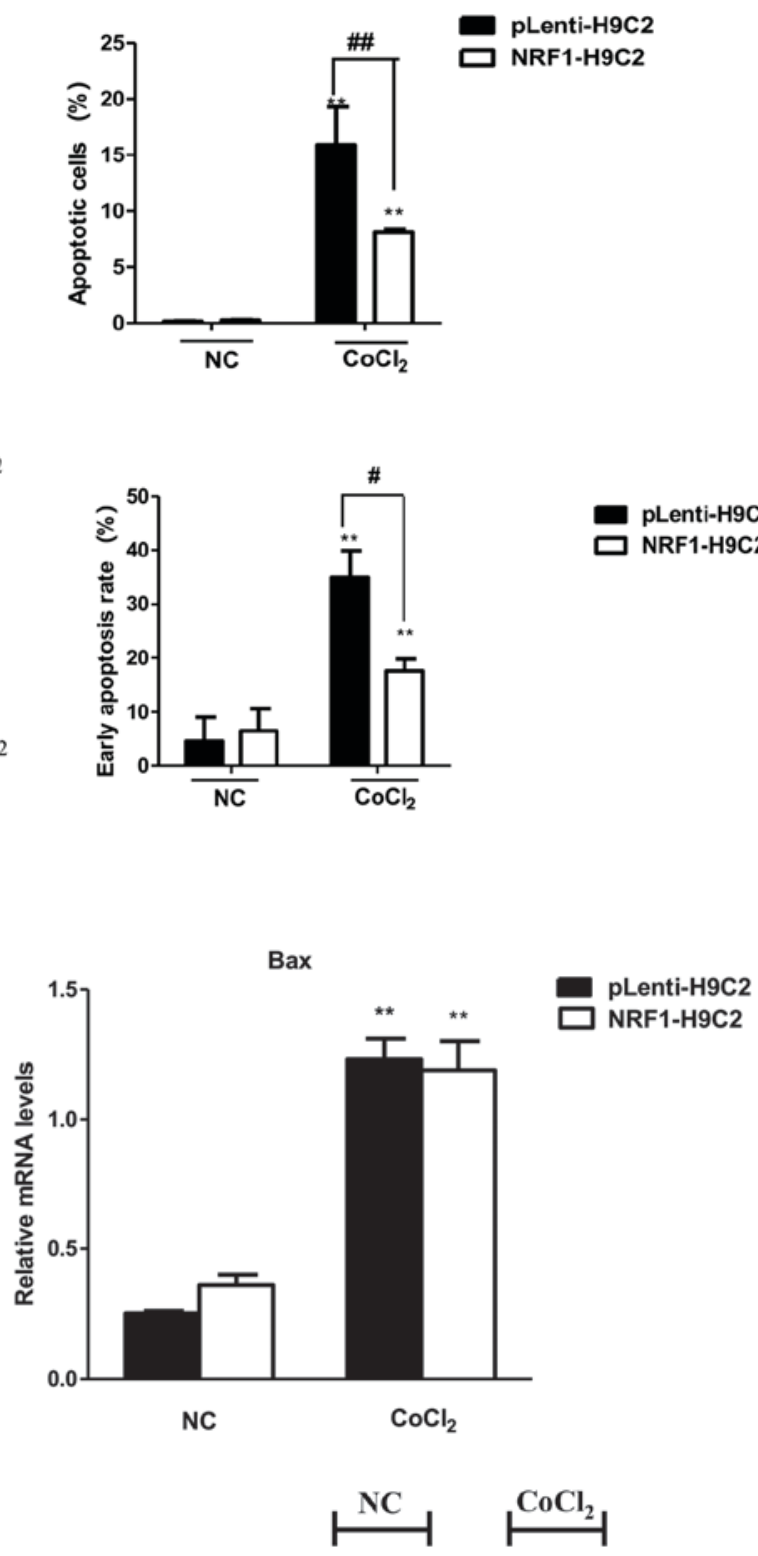

Bcl-2

$\beta$-actin

pLentin-H9C2

NRF1-H9C2

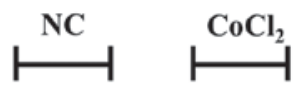

Bax

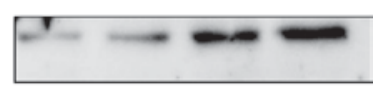

Cleaved PARP

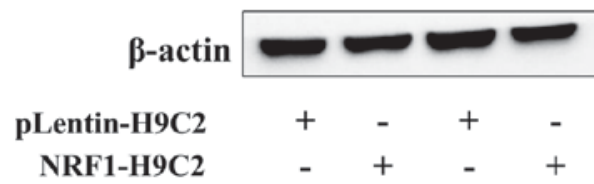

Figure 2. Effects of $\mathrm{CoCl}_{2}$ on apoptosis. (A) Changes in nuclear morphology, representative of apoptosis, in cells induced by $\mathrm{CoCl}{ }_{2}$ ( $400 \mu \mathrm{M}$ ) for $6 \mathrm{~h}$ were observed by Hoechst 33342 staining in pLenti-H9C 2 and NRF1-H9C 2 cells. Cells with intense blue staining in nuclei were counted. Magnification, $\mathrm{x} 400$. (B) Flow cytometry was used to detect apoptosis following staining with Annexin V-APC and 7-ADD. (C) mRNA expression of Bcl-2 and Bax was analyzed by reverse transcription-quantitative polymerase chain reaction. (D) Protein expression levels of NRF-1, Bcl-2, Bax and PARP were analyzed by western blot. ${ }^{* *} \mathrm{P}<0.01$ vs. $\mathrm{NC} ;{ }^{\#} \mathrm{P}<0.05,{ }^{\# \#} \mathrm{P}<0.01$ vs. pLenti-H9C2 cells. $\mathrm{NC}$, negative control $\left(\mathrm{CoCl}_{2}\right.$ untreated cells); $\mathrm{CoCl}{ }_{2}$, cobalt chloride; $\mathrm{NRF}$, nuclear respiratory factor; 7-AAD, 7-aminoactinomycin D; APC, allophycocyanin; Bcl-2, B-cell lymphoma-2; Bax, Bcl-associated X protein; PARP, poly(ADP-ribose) polymerase 1. 

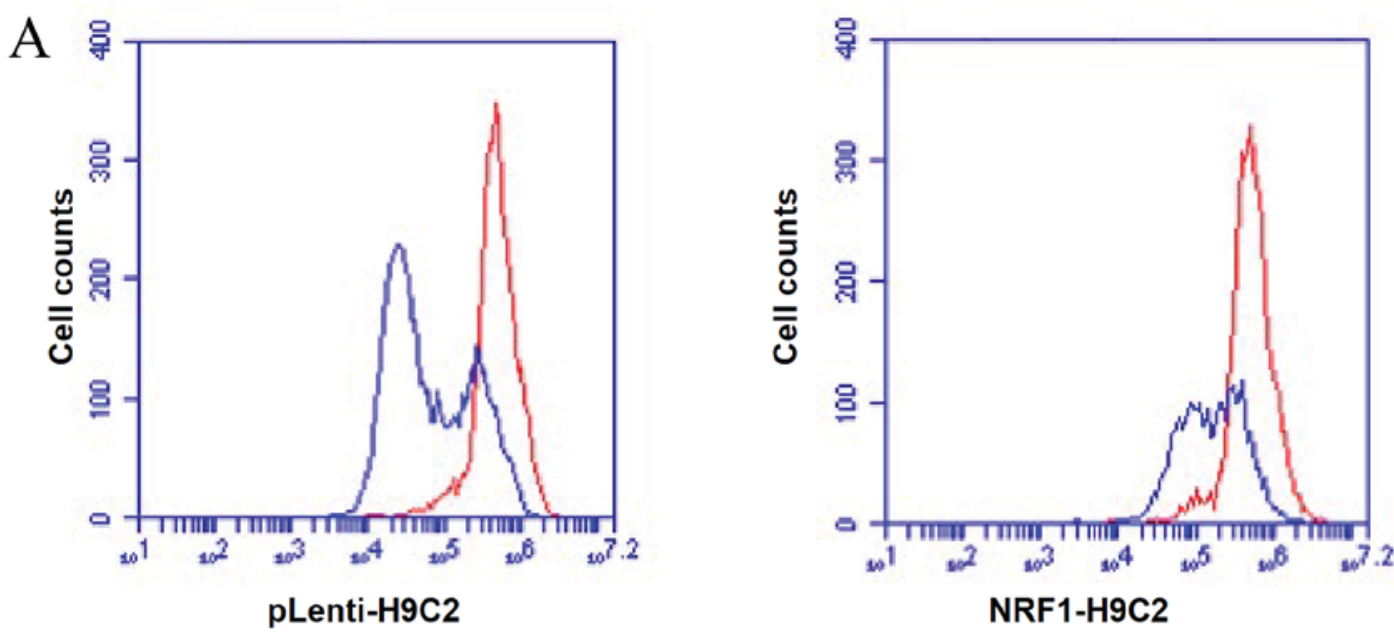

B

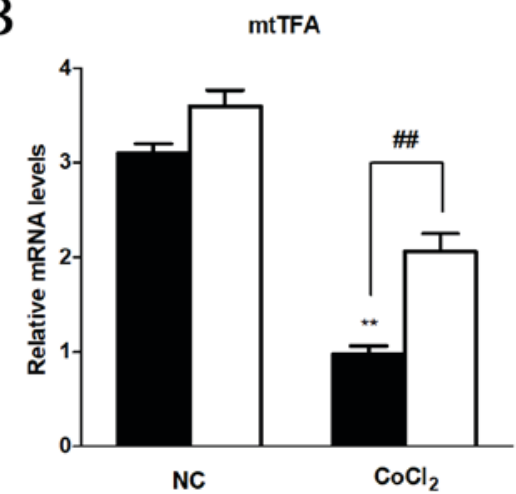

mtSSB

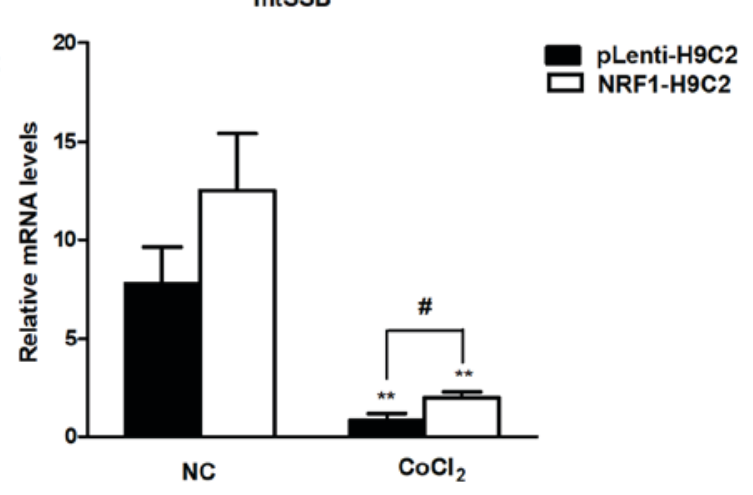

Figure 3. Effects of $\mathrm{CoCl}_{2}$ on mitochondrial membrane potential and the mRNA expression of $m t T F A$ and $m t S S B$ in $\mathrm{H} 9 \mathrm{C} 2$ cells. (A) Changes in mitochondrial membrane potential in pLenti-H9C2 and NRF1-H9C2. The cells were treated with $400 \mu \mathrm{M} \mathrm{CoCl}_{2}$ for $6 \mathrm{~h}$. The red curve represented the untreated cells, the blue curve represented the $\mathrm{CoCl}_{2}$-treated cells. (B) Reverse transcription-quantitative polymerase chain reaction was used to analyze $m t T F A$ and $m t S S B$ mRNA expression levels in pLenti-H9C2 and NRF1-H9C2 cells. ${ }^{* *} \mathrm{P}<0.01$ vs. NC group $\left(\mathrm{CoCl}_{2}\right.$ untreated cells); ${ }^{\#} \mathrm{P}<0.05$, ${ }^{\# \#} \mathrm{P}<0.01$ vs. $\mathrm{pLenti}-\mathrm{H} 9 \mathrm{C} 2$ cells. NRF, nuclear respiratory factor; $\mathrm{CoCl}_{2}$, cobalt chloride; mtTFA, mitochondrial transcription factor; mtSSB, mitochondrial single stranded DNA binding protein; $\mathrm{NC}$, negative control.

NRF-1 is involved in the integration of nuclear and mitochondrial genes (20,22); however, few studies have evaluated the protective effects of NRF-1 on $\mathrm{CoCl}_{2}$-induced cell damage (65). NRF-2, together with NRF-1, serves a key role in the integration of nuclear and mitochondrial genomes by directly or indirectly regulating the expression of nuclear-encoded genes (66-68). Various studies have focused on NRF-2, which has been described as a 'multi-organ protector' and can protect against many diseases in a number of organs (69), including chronic obstructive pulmonary disease, nephrotoxicity from ischemia-reperfusion injury and cisplatin and cardiomyopathy induced by smoking (70). Furthermore, inhibition of NRF-2 can render cells susceptible to apoptosis $(71,72)$ and has been shown to weaken endoplasmic reticulum stress-induced apoptosis in some experiments $(73,74)$. Additionally, NRF-2 is a crucial regulator of the response to cobalt and can be activated in response to $\mathrm{CoCl}_{2}$-mediated oxidative stress (75). In the present study, both NRF-2 and NRF-1 increased in $\mathrm{CoCl}_{2}$-treated $\mathrm{H} 9 \mathrm{C} 2$ cells, a previous study demonstrated that there are four antioxidant-responsive elements in the promoter region of $N R F-1$ that can be regulated by NRF-2, leading to an increase of NRF-1 protein levels (76); thus, whether the results of the present study indicated that there exists an interaction between NRF-1 and NRF-2, or whether their increase does not depend on each other in $\mathrm{CoCl}_{2}$-treated cells but is a mutual independence, requires more precise data to elucidate. The findings of the present study also indicated that the reduced proliferation of $\mathrm{CoCl}_{2}$-treated $\mathrm{H} 9 \mathrm{C} 2$ cells was partially due to the occurrence of apoptosis, and overexpression of NRF-1 alleviated $\mathrm{CoCl}_{2}$-induced apoptosis; this pro-survival effect was consistent with other studies $(63,76)$, suggesting that NRF-1 has an anti-apoptotic role, similar to NRF-2 (70).

Bcl-2 and Bax are two important apoptotic factors that are part of the Bcl-2 family, although they are classified into different groups based on their functions and structures: $\mathrm{Bcl}-2$ is an anti-apoptotic molecule, whereas Bax is a pro-apoptotic molecule, an entry point for the intrinsic apoptotic signaling pathway (77), and can be activated by various stimuli, ultimately leading to cell death (77-80). Bax activates caspase-9 (81), regulates the unfolded protein response by interacting with inositol requiring 1- $\alpha$ (82) and also modulates mitochondrial function (83). Bax and Bcl-2 are highly homologous and can form heterodimers (84). A number of studies have suggested that $\mathrm{Bcl}-2$ is an anti-apoptotic protein (85-88). 

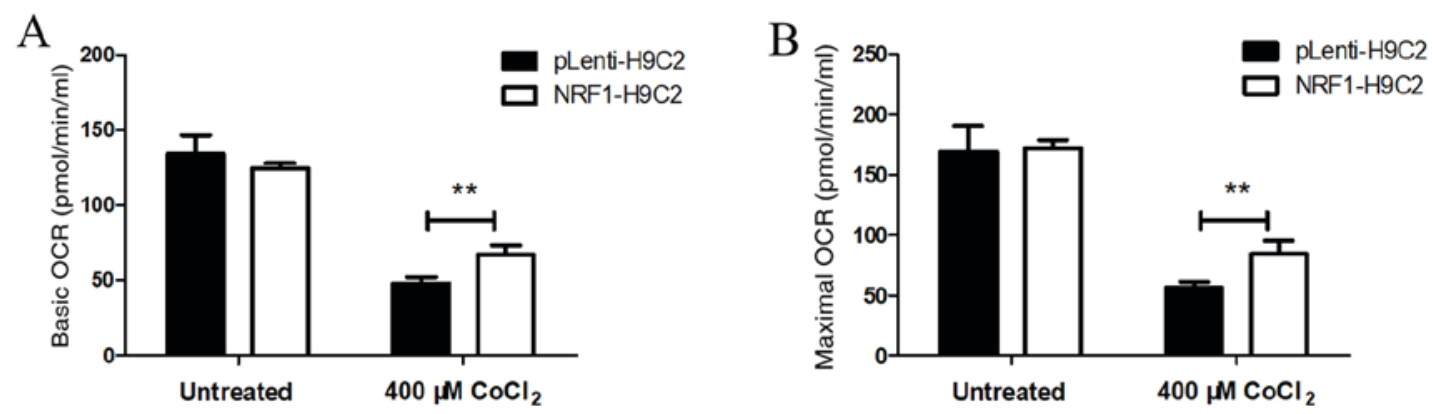

Figure 4. Detection of mitochondrial OCRs. (A) The basic and maximum OCR in untreated cells was detected. (B) The basic and maximum OCR in cells treated with $400 \mu \mathrm{M} \mathrm{CoCl}_{2}$ for $6 \mathrm{~h}$ was detected. ${ }^{* *} \mathrm{P}<0.01$ vs. pLenti-H9C2 cells. FCCP, carbonyl cyanide-p-trifluoromethoxyphenylhydrazone; $\mathrm{CoCl}_{2}, \mathrm{Cobalt}$ chloride; NRF, nuclear respiratory factor.

Therefore, the opposing roles of Bcl-2 and Bax are important in studies of apoptosis. Levels of Bax were increased in $\mathrm{CoCl}_{2}$-treated cells, and $\mathrm{Bcl}$-2 levels reduced in $\mathrm{CoCl}_{2}$-treated pLenti-H9C2. Notably, no differences were observed in Bax expression between pLenti-H9C2 and NRF1-H9C2 cells, suggesting that the inhibitory effects of NRF-1 on apoptosis may be associated with the transcriptional activation of Bcl-2. Furthermore, expression levels of the cleaved PARP were lower in NRF1-H9C2 cells compared with the pLenti vector control following treatment with $\mathrm{CoCl}_{2}$. These protective effects indicated that NRF-1 may mediate resistance to apoptosis. Additionally, when the incubation time was increased to $24 \mathrm{~h}$, the cytoprotective effects of NRF-1 were not observed, possibly because the notable decrease in NRF-1 removed the defense against $\mathrm{CoCl}_{2}$ damage.

The main mechanisms of apoptosis are the mitochondrial pathway and the death receptor pathway. Stress-induced mitochondrial dysfunction can severely affect cell survival and result in apoptotic cell death (89-93). NRF-1 was originally identified in a study of the promoter activity of cytochrome $c(94,95)$, an electron transport vehicle that can shuttle between different complexes; this feature has become an important target for the study of transcriptional regulation of various mitochondria-associated genes (96). Further in-depth studies have revealed that there are NRF-1 recognition sites in the promoter regions of several nuclear genes required for the expression of respiratory genes (97-101). Thus, the anti-apoptotic and pro-survival effects of NRF-1 on $\mathrm{CoCl}_{2}$-treated $\mathrm{H} 9 \mathrm{C} 2$ cells may be associated with the maintenance of mitochondrial function. Previous studies have demonstrated that MMP has a critical role in the maintenance of mitochondrial function $(102,103)$. Disruption of MMP can cause cytochrome $c$ to enter the cytosol, inducing apoptosis (104-106). The present findings indicated that overexpression of NRF-1 reduced the depolarization of MMP caused by $400 \mu \mathrm{M} \mathrm{CoCl}_{2}$. In addition, the present results demonstrated that NRF-1 may enhance the expression of the $m t T F A$ gene, consistent with previous studies (99). mtTFA is important for the initiation and transcription of mitochondria-encoded genes (107-109). These data suggest that in response to injury caused by $\mathrm{CoCl}_{2}$ and to maintain adequate mitochondrial functionality, NRF-1 can increase the expression of mitochondria-associated genes, mtTFA and mtSSB, thereby regulating mtDNA transcription and replication (110-112), and protecting the cell from stress.
MMP can effectively promote the synthesis of ATP by generating electrochemical gradients. It was speculated that disruption of MMP may inhibit the cellular mitochondrial respiratory capacity. In the present study, mitochondrial respiration was investigated by detecting the OCR of $\mathrm{CoCl}_{2}$-treated NRF1-H9C2 and pLenti-H9C2 cells. Mitochondrial respiratory potential has been measured as an index of oxidative stress-mediated mitochondrial dysfunction in previous studies $(49,113)$. In the present study, there was a significant decrease in mitochondrial respiration in $\mathrm{CoCl}_{2}$-treated cells, and overexpression of NRF-1 subsequently enhanced mitochondrial respiration. Thus, these findings revealed that NRF-1 may be involved in the regulation of mitochondrial function.

In summary, NRF-1 acted as an important anti-apoptotic molecule in $\mathrm{CoCl}_{2}$-treated $\mathrm{H} 9 \mathrm{C} 2$ cells, potentially by reducing the decrease in MMP and increasing mitochondrial respiration to strengthen cellular adaptability in the context of $\mathrm{CoCl}_{2}$-induced hypoxia.

\section{Acknowledgements}

The authors thank the members of the Institute of Medical Sciences of Ningxia Hui Autonomous Region for providing excellent technical assistance.

\section{Funding}

This project was supported by the National Natural Science Foundation of China (grant no. 81360042).

\section{Availability of data and materials}

The analyzed data sets generated during the study are available from the corresponding author on reasonable request.

\section{Authors' contributions}

$\mathrm{NN}, \mathrm{WZ}, \mathrm{ZHL}$ and RS contributed to writing the manuscript and revision. RS and WZ designed and revised the experiments. NN and ZHL wrote the manuscript and performed cell experiments. NN, HLS and SMX performed detection of energy metabolism. ZHL and MXZ prepared the images. MXZ performed the packaging of the virus. JHY performed flow cytometry assay. 


\section{Ethics approval and consent to participate}

Not applicable.

\section{Patient consent for publication}

Not applicable.

\section{Competing interests}

The authors declare that there are no competing interests.

\section{References}

1. Ratcliffe P, Koivunen P, Myllyharju J, Ragoussis J, Bovée JV, Batinic-Haberle I, Vinatier C, Trichet V, Robriquet F, Oliver L and Gardie B: Update on hypoxia-inducible factors and hydroxylases in oxygen regulatory pathways: From physiology to therapeutics. Hypoxia (Auckl) 5: 11-20, 2017.

2. Romero JI, Holubiec MI, Tornatore TL, Rivière S, Hanschmann EM, Kölliker-Frers RA, Tau J, Blanco E, Galeano P, Rodríguez de Fonseca F, et al: Neuronal damage induced by perinatal asphyxia is attenuated by postinjury glutaredoxin-2 administration. Oxid Med Cell Longev 2017: 4162465, 2017.

3. Keel M and Trentz O: Pathophysiology of polytrauma. Injury 36: 691-709, 2005

4. Grifka RG: Cyanotic congenital heart disease with increased pulmonary blood flow. Pediatr Clin North Am 46: 405-425, 1999

5. Ostadal B, Ostadalova I and Dhalla NS: Development of cardiac sensitivity to oxygen deficiency: Comparative and ontogenetic aspects. Physiol Rev 79: 635-659, 1999.

6. Bär H, Kreuzer J, Cojoc A and Jahn L: Upregulation of embryonic transcription factors in right ventricular hypertrophy. Basic Res Cardiol 98: 285-294, 2003.

7. Murray CJ and Lopez AD: Alternative projections of mortality and disability by cause 1990-2020: Global burden of disease study. Lancet 349: 1498-1504, 1997.

8. Yach D, Hawkes C, Gould CL and Hofman KJ: The global burden of chronic diseases: Overcoming impediments to prevention and control. JAMA 291: 2616-2622, 2004.

9. Akhmedov AT, Rybin V and Marín-García J: Mitochondrial oxidative metabolism and uncoupling proteins in the failing heart. Heart Fail Rev 20: 227-249, 2015.

10. Ingwall JS: ATP and the Heart: An Overview. Springer US, 2002.

11. Ong SB and Hausenloy DJ: Mitochondrial morphology and cardiovascular disease. Cardiovasc Res 88: 16-29, 2010.

12. Ventura-Clapier R, Garnier A, Veksler V and Joubert F: Bioenergetics of the failing heart. Biochim Biophys Acta 1813: 1360-1372, 2011

13. Hausenloy DJ and Ruiz-Meana M: Not just the powerhouse of the cell: Emerging roles for mitochondria in the heart. Cardiovasc Res 88: 5-6, 2010.

14. Soubannier V and Mcbride HM: Positioning mitochondrial plasticity within cellular signaling cascades. Biochim Biophys Acta 1793: 154-170, 2009.

15. Dominic EA, Ramezani A, Anker SD, Verma M, Mehta N and Rao M: Mitochondrial cytopathies and cardiovascular disease. Heart 100: 611-618, 2014

16. Saraste M: Oxidative phosphorylation at the fin de siècle. Science 283: 1488-1493, 1999.

17. Bianca B and Montagna E: The advances and new technologies for the study of mitochondrial diseases. Einstein (Sao Paulo) 14 291-293, 2016 (In English, Portuguese).

18. Björkholm P, Harish A, Hagström E, Ernst AM and Andersson SG: Mitochondrial genomes are retained by selective constraints on protein targeting. Proc Natl Acad Sci USA 112: 10154-10161, 2015

19. El-Hattab AW and Fernando S: Mitochondrial Cardiomyopathies. Front Cardiovasc Med 3: 25, 2016.

20. Evans MJ and Scarpulla RC: NRF-1: A trans-activator of nuclear-encoded respiratory genes in animal cells. Genes Dev 4 1023-1034, 1990

21. Huo L and Scarpulla RC: Mitochondrial DNA instability and peri-implantation lethality associated with targeted disruption of nuclear respiratory factor 1 in mice. Mol Cell Biol 21: 644-654, 2001
22. Scarpulla RC: Nuclear respiratory factors and the pathways of nuclear-mitochondrial interaction. Trends Cardiovasc Med 6: 39-45, 1996.

23. Scarpulla RC: Nuclear control of respiratory gene expression in mammalian cells. J Cell Biochem 97: 673-683, 2006.

24. Virbasius CA, Virbasius JV and Scarpulla RC: NRF-1, an activator involved in nuclear-mitochondrial interactions, utilizes a new DNA-binding domain conserved in a family of developmental regulators. Genes Dev 7: 2431-2445, 1993.

25. Clayton DA: Transcription and replication of animal mitochondrial DNAs. Int Rev Cytol 141: 217-232, 1992.

26. Choi YS, Kim S, Kyu LH, Lee KU and Pak YK: In vitro methylation of nuclear respiratory factor-1 binding site suppresses the promoter activity of mitochondrial transcription factor A. Biochem Biophy Res Commun 314: 118-122, 2004.

27. Piantadosi CA and Suliman HB: Mitochondrial transcription factor A induction by redox activation of nuclear respiratory factor 1. J Biol Chem 281: 324-333, 2006.

28. Zhang L, Bao Y, Liu Y and Li J: Downregulation of nuclear respiratory factor-1 contributes to mitochondrial events induced by benzo(a)pyrene. Environ Toxicol 29: 780-787, 2014

29. Suliman HB, Sweeney TE, Withers CM and Piantadosi CA: Co-regulation of nuclear respiratory factor-1 by NFkappaB and CREB links LPS-induced inflammation to mitochondrial biogenesis. J Cell Sci 123: 2565-2575, 2010.

30. Piantadosi CA and Suliman HB: Transcriptional regulation of SDHa flavoprotein by nuclear respiratory factor-1 prevents pseudo-hypoxia in aerobic cardiac cells. J Biol Chem 283 10967-10977, 2008.

31. Wang GL and Semenza GL: Characterization of hypoxia-inducible factor 1 and regulation of DNA binding activity by hypoxia. J Biol Chem 268: 21513-21518, 1993.

32. Wang GL and Semenza GL: Desferrioxamine induces erythropoietin gene expression and hypoxia-inducible factor 1 DNA-binding activity: Implications for models of hypoxia signal transduction. Blood 82: 3610-3615, 1993.

33. Hervouet E, Pecina P, Demont J, Vojtísková A, Simonnet H, Houstek J and Godinot C: Inhibition of cytochrome c oxidase subunit 4 precursor processing by the hypoxia mimic cobalt chloride. Biochem Biophys Res Commun 344: 1086-1093, 2006.

34. Zhang YB, Wang X, Meister EA, Gong KR, Yan SC, Lu GW, Ji XM and Shao G: The effects of $\mathrm{CoCl}_{2}$ on HIF-1 $\alpha$ protein under experimental conditions of autoprogressive hypoxia using mouse models. Int J Mol Sci 15: 10999-11012, 2014.

35. Jaakkola P, Mole DR, Tian YM, Wilson MI, Gielbert J, Gaskell SJ, von Kriegsheim A, Hebestreit HF, Mukherji M, Schofield CJ, et al: Targeting of HIF-alpha to the von Hippel-Lindau ubiquitylation complex by $\mathrm{O}_{2}$-regulated prolyl hydroxylation. Science 292: 468-472, 2001

36. Kaelin WG Jr: The von Hippel-Lindau tumor suppressor gene and kidney cancer. Clin Cancer Res 10: 6290S-6295S, 2004.

37. Taylor MS: Characterization and comparative analysis of the EGLN gene family. Gene 275: 125-132, 2001

38. Bae S, Jeong HJ, Cha HJ, Kim K, Choi YM, An IS, Koh HJ, Lim DJ, Lee SJ and An S: The hypoxia-mimetic agent cobalt chloride induces cell cycle arrest and alters gene expression in U266 multiple myeloma cells. Int J Mol Med 30: 1180-1186, 2012.

39. Shrivastava K, Ram MS, Bansal A, Singh SS and Ilavazhagan G: Cobalt supplementation promotes hypoxic tolerance and facilitates acclimatization to hypobaric hypoxia in rat brain. High Alt Med Biol 9: 63-75, 2008.

40. Shrivastava K, Shukla D, Bansal A, Sairam M, Banerjee PK and Ilavazhagan G: Neuroprotective effect of cobalt chloride on hypobaric hypoxia-induced oxidative stress. Neurochem Int 52 : 368-375, 2008

41. Araya J, Maruyama M, Inoue A, Fujita T, Kawahara J, Sassa K, Hayashi R, Kawagishi Y, Yamashita N, Sugiyama E and Kobayashi M: Inhibition of proteasome activity is involved in cobalt-induced apoptosis of human alveolar macrophages. Am J Physiol Lung Cell Mol Physiol 283: L849-L858, 2002.

42. Mecklenburgh KI, Walmsley SR, Cowburn AS, Wiesener M, Reed BJ, Upton PD, Deighton J, Greening AP and Chilvers ER: Involvement of a ferroprotein sensor in hypoxia-mediated inhibition of neutrophil apoptosis. Blood 100: 3008-3016, 2002.

43. Tello D, Balsa E, Acosta-Iborra B, Fuertes-Yebra E, Elorza A, Ordóñez Á, Corral-Escariz M, Soro I, López-Bernardo E, Perales-Clemente E, et al: Induction of the mitochondrial NDUFA4L2 protein by HIF-1 $\alpha$ decreases oxygen consumption by inhibiting Complex I activity. Cell Metab 14: 768-779, 2011. 
44. Livak KJ and Schmittgen TD: Analysis of relative gene expression data using real-time quantitative PCR and the 2(-Delta Delta C(T)) method. Methods 25: 402-408, 2001.

45. Tischlerova V, Kello M, Budovska M and Mojzis J: Indole phytoalexin derivatives induce mitochondrial-mediated apoptosis in human colorectal carcinoma cells. World J Gastroenterol 23: 4341-4353, 2017.

46. Venkatarame Gowda Saralamma V, Lee HJ, Hong GE, Park HS, Yumnam S, Raha S, Lee WS, Kim EH, Sung NJ, Lee SJ, et al: Korean Scutellaria baicalensis Georgi flavonoid extract induces mitochondrially mediated apoptosis in human gastric cancer AGS cells. Oncol Lett 14: 607-614, 2017.

47. Wang L, Gao S, Jiang W, Luo C, Xu M, Bohlin L, Rosendahl M and Huang W: Antioxidative dietary compounds modulate gene expression associated with apoptosis, DNA repair, inhibition of cell proliferation and migration. Int J Mol Sci 15: 16226-16245, 2014.

48. Wang Y, Yu RY and He QY: Proteomic analysis of anticancer TCMs targeted at mitochondria. Evid Based Complement Alternat Med 2015: 539260, 2015.

49. Kogot-Levin A, Saada A, Leibowitz G, Soiferman D, Douiev L, Raz I and Weksler-Zangen S: Upregulation of mitochondrial content in cytochrome c oxidase deficient fibroblasts. PLoS One 11: e0165417, 2016

50. van der Windt GJ, Everts B, Chang CH, Curtis JD, Freitas TC, Amiel E, Pearce EJ and Pearce EL: Mitochondrial respiratory capacity is a critical regulator Of $\mathrm{CD} 8+\mathrm{T}$ cell memory development. Immunity 36: 68-78, 2012.

51. Paradis AN, Gay MS and Zhang L: Binucleation of cardiomyocytes: The transition from a proliferative to a terminally differentiated state. Drug Discovery Today 19: 602-609, 2014.

52. Li F, Wang X, Capasso JM and Gerdes AM: Rapid transition of cardiac myocytes from hyperplasia to hypertrophy during postnatal development. J Mol Cell Cardiol 28: 1737-1746, 1996.

53. Ahuja P, Sdek P and Maclellan WR: Cardiac myocyte cell cycle control in development, disease, and regeneration. Physiol Rev 87: 521-544, 2007.

54. Burrell JH, Boyn AM, Kumarasamy V, Hsieh A, Head SI and Lumbers ER: Growth and maturation of cardiac myocytes in fetal sheep in the second half of gestation. Anat Rec A Discov Mol Cell Evol Biol 274: 952-961, 2003.

55. Ostádal B, Ostádalová I, Kolár F, Charvátová Z and Netuka I: Ontogenetic development of cardiac tolerance to oxygen deprivation-possible mechanisms. Physiol Res 58 (Suppl 2): S1-S12, 2009.

56. Dai M, Cui P, Yu M, Han J, Li H and Xiu R: Melatonin modulates the expression of VEGF and HIF-1 alpha induced by $\mathrm{CoCl}_{2}$ in cultured cancer cells. J Pineal Res 44: 121-126, 2008.

57. Jiang Y, Satoh K, Watanabe S, Kusama K and Sakagami H: Inhibition of chlorogenic acid-induced cytotoxicity by $\mathrm{CoCl}_{2}$. Anticancer Res 21: 3349-3353, 2001.

58. Jung JY, Mo HC, Yang KH, Jeong YJ, Yoo HG, Choi NK, Oh WM, Oh HK, Kim SH, Lee JH, et al: Inhibition by epigallocatechin gallate of $\mathrm{CoCl}_{2}$-induced apoptosis in rat PC12 cells Life Sci 80: 1355-1363, 2007

59. Chen R, Xu J, She Y, Jiang T, Zhou S, Shi $\mathrm{H}$ and Li C: Necrostatin-1 protects $\mathrm{C} 2 \mathrm{C} 12$ myotubes from $\mathrm{CoCl}_{2}$-induced hypoxia. Int J Mol Med 41: 2565-2572, 2018.

60. Chen R, Jiang T, She Y, Xu J, Li C, Zhou S, Shen H, Shi H and Liu S: Effects of cobalt chloride, a hypoxia-mimetic agent, on autophagy and atrophy in skeletal C2C12 myotubes. Biomed Res Int 2017: 7097580, 2017.

61. Rovetta F, Stacchiotti A,Faggi F, Catalani S, Apostoli P,Fanzani A and Aleo MF: Cobalt triggers necrotic cell death and atrophy in skeletal C2C12 myotubes. Toxicol Appl Pharmacol 271: 196-205, 2013.

62. Bartz RR, Suliman HB and Piantadosi CA: Redox mechanisms of cardiomyocyte mitochondrial protection. Front Physiol 6: 291, 2015.

63. Chen L, Kwong M, Lu R, Ginzinger D, Lee C, Leung L and Chan JY: Nrf1 is critical for redox balance and survival of liver cells during development. Mol Cell Biol 23: 4673-4686, 2003.

64. Doerks T, Copley RR, Schultz J, Ponting CP and Bork P: Systematic identification of novel protein domain families associated with nuclear functions. Genome Res 12: 47-56, 2002.

65. Saxena S, Shukla D, Saxena S, Khan YA, Singh M, Bansal A, Sairam M and Jain SK: Hypoxia preconditioning by cobalt chloride enhances endurance performance and protects skeletal muscles from exercise-induced oxidative damage in rats. Acta Physiol (Oxf) 200: 249-263, 2010
66. Priya A, Johar K and Wong-Riley M: Nuclear respiratory factor 2 regulates the expression of the same NMDA receptor subunit genes as NRF-1: Both factors act by a concurrent and parallel mechanism to couple energy metabolism and synaptic transmission. Biochim Biophys Acta 1833: 48-58, 2013.

67. Priya A, Johar K, Nair B and Wong-Riley MT: Nuclear respiratory factor 2 regulates the transcription of AMPA receptor subunit GluA2 (Gria2). Biochim Biophys Acta 1843: 3018-3028, 2014.

68. Vercauteren K, Gleyzer N and Scarpulla RC: PGC-1-related coactivator complexes with HCF-1 and NRF-2beta in mediating NRF-2(GABP)-dependent respiratory gene expression. J Biol Chem 283: 12102-12111, 2008.

69. Lee JM, Li J, Johnson DA, Stein TD, Kraft AD, Calkins MJ, Jakel RJ and Johnson JA: Nrf2, a multi-organ protector? FASEB J 19: 1061-1066, 2005.

70. Liby KT and Sporn MB: Synthetic oleanane triterpenoids: Multifunctional drugs with a broad range of applications for prevention and treatment of chronic disease. Pharmacol Rev 64: 972-1003, 2012.

71. Arlt A, Sebens S, Krebs S, Geismann C, Grossmann M, Kruse ML, Schreiber S and Schäfer H: Inhibition of the Nrf2 transcription factor by the alkaloid trigonelline renders pancreatic cancer cells more susceptible to apoptosis through decreased proteasomal gene expression and proteasome activity. Oncogene 32: 4825-4835, 2013.

72. Arlt A, Bauer I, Schafmayer C, Tepel J, Müerköster SS, Brosch M, Röder C, Kalthoff H, Hampe J, Moyer MP, et al: Increased proteasome subunit protein expression and proteasome activity in colon cancer relate to an enhanced activation of nuclear factor E2-related factor 2 (Nrf2). Oncogene 28: 3983-3996, 2009.

73. Calvert JW, Elston M, Nicholson CK, Gundewar S, Jha S, Elrod JW, Ramachandran A and Lefer DJ: Genetic and pharmacologic hydrogen sulfide therapy attenuates ischemia-induced heart failure in mice. Circulation 122: 11-19, 2010.

74. Malhotra D, Thimmulappa R, Vij N, Navas-Acien A, Sussan T, Merali S, Zhang L, Kelsen SG, Myers A, Wise R, et al: Heightened endoplasmic reticulum stress in the lungs of patients with chronic obstructive pulmonary disease: The role of Nrf2-regulated proteasomal activity. Am J Respir Crit Care Med 180: 1196-1207, 2009.

75. Permenter MG, Dennis WE, Sutto TE, Jackson DA, Lewis JA and Stallings JD: Exposure to cobalt causes transcriptomic and proteomic changes in two rat liver derived cell lines. PLoS One 8: e83751,2013.

76. Piantadosi CA, Carraway MS, Babiker A and Suliman HB: Heme oxygenase-1 regulates cardiac mitochondrial biogenesis via Nrf2-mediated transcriptional control of nuclear respiratory factor-1. Circ Res 103: 1232-1240, 2008.

77. Liu Z, Ding Y, Ye N, Wild C, Chen H and Zhou J: Direct activation of Bax protein for cancer therapy. Med Res Rev 36: 313-341, 2016.

78. Brenner D and Mak TW: Mitochondrial cell death effectors. Curr Opin Cell Biol 21: 871-877, 2009.

79. Pagliari LJ, Kuwana T, Bonzon C, Newmeyer DD, Tu S, Beere HM and Green DR: The multidomain proapoptotic molecules Bax and Bak are directly activated by heat. Proc Natl Acad Sci USA 102: 17975-17980, 2005.

80. Yin C, Knudson CM, Korsmeyer SJ and Van DT: Bax suppresses tumorigenesis and stimulates apoptosis in vivo. Nature 385: 637-640, 1997.

81. Li P, Nijhawan D, Budihardjo I, Srinivasula SM, Ahmad M, Alnemri ES and Wang X: Cytochrome $c$ and dATP-dependent formation of Apaf-1/caspase-9 complex initiates an apoptotic protease cascade. Cell 91: 479-489, 1997.

82. Rampino N, Yamamoto H, Ionov Y, Li Y, Sawai H, Reed JC and Perucho M: Somatic frameshift mutations in the BAX gene in colon cancers of the microsatellite mutator phenotype. Science 275: 967-969, 1997.

83. Karbowski M, Norris KL, Cleland MM, Jeong SY and Youle RJ: Role of Bax and Bak in mitochondrial morphogenesis. Nature 443: 658-662, 2006.

84. Walensky LD and Gavathiotis E: BAX unleashed: The biochemical transformation of an inactive cytosolic monomer into a toxic mitochondrial pore. Trends Biochem Sci 36: 642-652, 2011.

85. Adams JM and Cory S: Bcl-2-regulated apoptosis: Mechanism and therapeutic potential. Curr Opin Immunol 19: 488-496, 2007.

86. Hata AN, Engelman JA and Faber AC: The BCL2 family: Key mediators of the apoptotic response to targeted anticancer therapeutics. Cancer Discov 5: 475-487, 2015. 
87. Kale J, Liu Q, Leber B and Andrews DW: Shedding light on apoptosis at subcellular membranes. Cell 151: 1179-1184, 2012.

88. Wood WG, Igbavboa U, Muller WE and Eckert GP: Statins, Bcl-2 and apoptosis: Cell death or cell protection? Mol Neurobiol 48: 308-314, 2013.

89. Gogvadze V and Orrenius S: Mitochondrial regulation of apoptotic cell death. Chem Biol Interact 163: 4-14, 2006.

90. Jeong SY and Seol DW: The role of mitochondria in apoptosis. BMB Rep 41: 11-22, 2008.

91. Park JB, Chang H and Kim KW: Expression of Fas ligand and apoptosis of disc cells in herniated lumbar disc tissue. Spine (Phila Pa 1976) 26: 618-621, 2001.

92.Park JB, Kim KW, Han CW and Chang H: Expression of Fas receptor on disc cells in herniated lumbar disc tissue. Spine (Phila Pa 1976) 26: 142-146, 2001.

93. Parsons MJ and Green DR: Mitochondria in cell death. Essays Biochem 47: 99-114, 2010.

94. Evans MJ and Scarpulla RC: Interaction of nuclear factors with multiple sites in the somatic cytochrome $c$ promoter Characterization of upstream NRF-1, ATF, and intron Spl recognition sequences. J Biol Chem 264: 14361-14368, 1989.

95. Evans MJ and Scarpulla RC: Both upstream and intron sequence elements are required for elevated expression of the rat somatic cytochrome $c$ gene in COS-1 cells. Mol Cell Biol 8: 35-41, 1988

96. Scarpulla RC and Wu R: Nonallelic members of the cytochrome $c$ multigene family of the rat may arise through different messenger RNAs. Cell 32: 473-482, 1983.

97. Chau CM, Evans MJ and Scarpulla RC: Nuclear respiratory factor 1 activation sites in genes encoding the gamma-subunit of ATP synthase, eukaryotic initiation factor 2 alpha, and tyrosine aminotransferase. Specific interaction of purified NRF-1 with multiple target genes. J Biol Chem 267: 6999-7006, 1992.

98. Kelly DP and Scarpulla RC: Transcriptional regulatory circuits controlling mitochondrial biogenesis and function. Genes Dev 18: 357-368, 2004

99. Scarpulla RC: Nuclear activators and coactivators in mammalian mitochondrial biogenesis. Biochim Biophys Acta 1576: $1-14,2002$

100. Scarpulla RC: Transcriptional activators and coactivators in the nuclear control of mitochondrial function in mammalian cells. Gene 286: 81-89, 2002

101. Scarpulla RC: Nuclear control of respiratory chain expression by nuclear respiratory factors and PGC-1-related coactivator. Ann NY Acad Sci 1147: 321-334, 2008.

102. Perry SW, Norman JP, Barbieri J, Brown EB and Gelbard HA: Mitochondrial membrane potential probes and the proton gradient: A practical usage guide. Biotechniques 50: 98-115, 2011.
103. Zhang BB, Wang DG, Guo FF and Xuan C: Mitochondrial membrane potential and reactive oxygen species in cancer stem cells. Fam Cancer 14: 19-23, 2015.

104. Henry-Mowatt J, Dive C, Martinou JC and James D: Role of mitochondrial membrane permeabilization in apoptosis and cancer. Oncogene 23: 2850-2860, 2004.

105. Lakhani SA, Masud A, Kuida K, Porter GA Jr, Booth CJ, Mehal WZ, Inayat I and Flavell RA: Caspases 3 and 7: Key mediators of mitochondrial events of apoptosis. Science 311: 847-851, 2006.

106. Ly JD, Grubb DR and Lawen A: The mitochondrial membrane potential (deltapsi(m)) in apoptosis; an update. Apoptosis 8 $115-128,2003$.

107. Campbell CT, Kolesar JE and Kaufman BA: Mitochondrial transcription factor A regulates mitochondrial transcription initiation, DNA packaging, and genome copy number. Biochim Biophys Acta 1819: 921-929, 2012.

108. Fisher RP and Clayton DA: Purification and characterization of human mitochondrial transcription factor 1. Mol Cell Biol 8 : 3496-3509, 1988

109. Parisi MA and Clayton DA: Similarity of human mitochondrial transcription factor 1 to high mobility group proteins. Science 252: 965-969, 1991.

110. Maier D, Farr CL, Poeck B, Alahari A, Vogel M, Fischer S, Kaguni LS and Schneuwly S: Mitochondrial single-stranded DNA-binding protein is required for mitochondrial DNA replication and development in Drosophila melanogaster. Mol Biol Cell 12: 821-830, 2001

111. Takamatsu C, Umeda S, Ohsato T, Ohno T, Abe Y, Fukuoh A, Shinagawa H, Hamasaki N and Kang D: Regulation of mitochondrial D-loops by transcription factor A and single-stranded DNA-binding protein. EMBO Rep 3: 451-456, 2002.

112. Van Dyck E, Foury F, Stillman B and Brill SJ: A single-stranded DNA binding protein required for mitochondrial DNA replication in S. cerevisiae is homologous to E. coli SSB. EMBO J 11: 3421-3430, 1992.

113. Mali VR, Pan G, Deshpande M, Thandavarayan RA, Xu J, Yang XP and Palaniyandi SS: Cardiac mitochondrial respiratory dysfunction and tissue damage in chronic hyperglycemia correlate with reduced aldehyde dehydrogenase-2 activity. PLoS One 11: e0163158, 2016.

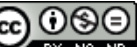

This work is licensed under a Creative Commons

Attribution-NonCommercial-NoDerivatives 4.0

International (CC BY-NC-ND 4.0) License. 